\title{
Bali Mūla Cosmology: A Case Study of Pura Pucak Panulisan as A Gebog Domas Center in Kintamani District Regency of Bangli, Bali Province
}

\author{
I Nyoman Wardi \\ \{wardiecoculture@gmail.co\} \\ Universitas Udayana Denpasar-Bali, Indonesia
}

\begin{abstract}
Pucak Panulisan Temple which is located at Sukawana Village, Kintamani District, stored various ancient cultural heritages. Among these are Pucak Panulisan Temple, known as the cosmological center of the Gebog Domas of the Bali Mūla (indigenous Balinese) community in Kintamani. This research aims to reveal the history of the Gebog Domas of the Bali Mūla community and the cosmological meaning of the Gebog Domas of the Bali Mula community.The study was conducted through data collection with observation techniques, in-depth interviews and literature studies. The collected data were analyzed descriptive-qualitatively with the Ethnoarchaeology and Cultural Semiotical approaches. The study showed the following results. The Gebog Domas cosmological concept which consists of four united Gebog Satak (Gebog Satak Sukawana, Kintamani, Selulung and Bantang) is thought to have originated from pre-Hindu (prehistoric) times. During in the Ancient Balinese Period (IX-XIV centuries AD), the Pucak Panulisan site was also functioned as a state temple in mountain (uranisch) when the kuta rajya (royal city) was centered in Pejeng-Bedulu-Gianyar. Cultural-Semiotically, the concept of Gebog Domas means: balance and harmony between microcosm-macrocosm, social integrity, order and peace of life, fertility (productivity), prosperity (jagadhita) in sustainable life. Now in the Postmodern era, the cultural wisdom embodied in the Gebog Domas cosmology is a challenge for local community (Bali-Mūla) to preserve and implement in real life.
\end{abstract}

Keywords - Bali mūla, cosmology, gebog domas, pucak panulisan

\section{Introduction}

In general, the Kintamani area which is a mountainous area inhabited by the Bali Mūla (indigenous Balinese), including the managers (pangempon) of Gebog Domas, which is centered in Pucak Panulisan Temple at Sukawana Village. Some researches have been done before. Among those, W.F. Stutterheim in his book entitled: "Oudheiden van Bali" (1929) ${ }^{[1]}$ mentioned the archeology (statues) at Pucak Panulisan Temple, especially the short inscriptions (behind statues), and the statues at Pura Pucak Panulisan. Meawhile R. Goris (no year) ${ }^{[2]}$ on 
his book entitled: Bali Atlas Kebudayaan, stated, that the great kingdom of the Ancient Bali era had state temples (kayangan jagat) and played an important role in the state (kingdom). Prior to Hinduism, temples were known in three different geographical regions, namely: (1) mountain sanctuaries (uranisch), (2) temple in the royal capital in the plains (central zone), and (3) temple existing in coastal area / at sea (chtonisch). In the three royal temples in different geographical areas, Pura Penataran Agung, located in the royal capital, is the center of the kingdom. Furthermore ${ }^{[3]}$ before the collapse of the kingdom of Ancient Bali by the rule of Majapahit (1343 AD), the Penataran Sasih-Pejeng Temple of the Balinese Hindu Age became the center of the Ancient Balinese kingdom. Meanwhile, Tegeh Koripan or Pucak Panulisan Temple of Sukawana Village, Kintamani District was regarded as a representation of the sacred sites of the ancient Balinese kingdom on the mountain.

Other researchers, ${ }^{[4]}$ in his research tends to be ethnographic and does not utilize Archeological data in its analysis. In this book, some of them reveal about the cultural traditions of the Balinese Mūla people in the mountainous areas, specifically Sukawana Village Kintamani and alluded to the Gebog Domas organization, but does not analyze the cosmological system in the context of environmental wisdom.

Gebog Domas of Pucak Panulisan at Sukawana Village is actually a worldview of the people of Bali Mūla (indigenous Balinese) in Kintamani District which associated with the traditional cosmological system. Regarding to cosmology as a form of myth from ancient societies, ${ }^{[5]}$ stated that in an ancient cultural view, religion maintains the 'opening' of relations to the superhuman world, that is, a world that has axiological value. These values are transcendent in the sense that they are related in uncovering divine beings or mythical ancestors. They are absolute values, namely as a paradigm in all human activities. This model is conveyed through myth. Myth, is the most common and effective means to awaken and maintain awareness of the existence of another world (the outside world), whether as a realm of divine (divine world) or a world of ancestral spirits (ancestral world). It becomes an experience that sacredness is in dealing with the reality of transhuman beings, then gives birth to the idea that something really exists, and since then, absolute value can guide humans and give meaning to the existence of their lives.

${ }^{[6]}$ The need to reconstruct religious cosmology with fresh thoughts because they have been abandoned by the positivistic (modern) scientific world and tend to be exploitative in nature. The importance of religious cosmology is because it is an ecological imperative and is built from an ethical and philosophical spiritual heritage from the past. Inside there are ethical, moral and spiritual treasures related to environmental wisdom.

Based on the description above, this research is considered quite interesting to reveal the environmental wisdom of the Bali Mūla cosmological system, namely Gebog Domas, which is centered in the Pucak Panulisan Temple site in Sukawana Village, Kintamani District, Bangli Regency.

\section{Methods}

The research was conducted through data collection and data analysis. Data collection is done by observation, in-depth interviews and literature / document studies. Observation was carried out directly into the field on the object being studied, namely Banua Gebog Domas, Kintamani District, Bangli Regency in order to obtain primary data. Interviews were conducted with key informants, including traditional villages / customary village heads, Kubayan / 
Kabayan (temple priests), and other relevant community leaders. Meanwhile, the literature study is carried out by exploring written data, in the form of research results or theoretical opinions from experts, both published in the form of books, journals, mass media (newspapers), internet data, or as yet unpublished. The collected data was then analyzed descriptivequalitatively using the Ethnoarchaeological approach [7] and Cultural Semiotical theory[8].

\section{Result and Discussion}

\subsection{Pucak Panulisan Temple Heritage and Site}

Pucak Panulisan Temple at Sukawana Village, Kintamani District, Bangli Regency, Bali Province is located on the terraced hills (elevation $1786 \mathrm{~m}$ asl) which reminds us of megalithic cultural traditions. Bukit Panulisan is a remnant of Ancient Mount Batur volcanism which collapsed around 29,300 years ago (first explosion), and the second explosion is estimated to have occurred 20,150 years ago ${ }^{[9]}$. The location of Pucak Panulisan Temple is on the Tjunction of Sukawana Village, Kintamani District. The distance is about $\pm 75 \mathrm{~m}$ from Denpasar City, Bali Province. According to R. Goris (no year), before the collapse of the Ancient Balinese kingdom by Majapahit rule (1343 AD), Pucak Bukit Panulisan Temple (Tegeh Koripan Temple) Sukawana Village was a representation of the Ancient Balinese royal sanctuary (IX-XIV century AD) on Mount (Uranisch). Pucak Panulisan Temple, which still functions as a living monument, holds dozens of embodied statues associated with the ancestors of the kings of Ancient Bali (AD XI and XIV centuries), several phallus statues, ecofacts and sacred buildings (palinggih). Now the Pucak Panulisan Temple still exists as the center of Banua Gebog Domas from the Bali Mūla (Bali Aga) community in the Kintamani District of Bangli Regency.

\subsection{Characteristic of the Bali Mūla Community}

Bali Mūla means early Bali or beginning, or native Balinese. Based on its socio-cultural characteristics, the Bali Mūla community is seen as part of the diaspora community who supporting Austronesian culture. Based on the findings of the grave (megalithic culture) made of stone (sarcophagus) scattered in almost all regions of the island of Bali, it can be interpreted that in the period before Bali was influenced by Indian (Hindu and Buddhist) culture, the existence of the Bali Mūla community was spread throughout the entire region Bali, eiher in coastal areas, the central zone (Bali Dataran), and in the highlands or mountainous areas (Bali Aga). Topogeographically, the current Bali Mūla community, mostly living in the highlands (mountains), so they are also known as the Bali Aga people (Mountainous Balinese). About the terminology of Bali Mūla and Bali Aga as Balinese identity, quite often cause debate among the intellectual community and among the public. In the context of the religious system, the cultural characteristics of the Bali Müla people (Bali Aga), are marked by the veneration of Animism and Ancestral Spirits which are very prominent and regarded deriving from Megalithic (Prehistoric) cultural traditions of the early AD period. In addition, one characteristic of the Bali Mūla community, namely the caste system is not known in its social stratification as Hindu society in general (Catur Kasta/Wangsa), namely Brahmin, Ksatrya, Wesya and Sudra. Implicitly the Bali Müla people can be stated to be quite egalitarian because there is unknown social stratification based on the caste which is mentioned above. They are in 
equality and commonly use (add) the letter $I$ (masculine) or $N i$ (feminine) in front of their numbering birth names, an then followed with their real names (surname), with some variants, such as: I (Ni ) Wayan .... (surname), I (Ni) Nengah / Made ... (name), I (Ni) Nyoman ... (name) and I (Ni) Ketut ... (name). In addition to the Bali Müla people, in Bali now also known as the Balinese group of Wong Majapahit, which generally inhabiting at more plain areas of Bali. The existence of Wong Bali Majapahit society which is colored by socio-cultural Hinduism, is generally associated with the migration history of Javanese Hindus after Ancient Balinese Kingdom dominated by the Majapahit Kingdom from East Java in 1334 AD. In social stratification, the Bali Majapahit society is very strongly colored by the Caste system (Catur Kasta/Wangsa). In its religious system, the worship of Hindu pantheons (especially the Tri Murti Gods: Brahma God / Creator of Nature, Wishnu / Protector and Preserver of Nature, and Çiwa / Melting God) is quite prominent, besides worshiping ancestral spirits and Animism. The acculturation and sedimentation of this socio-cultural history make the characteristics of traditional Balinese culture very unique (distinctive) and rich, and now become a strategic cultural asset, which is a very popular as international tourist attraction.

\subsection{The Cosmology of Gebog Domas Pucak Panulisan Temple}

In the cosmological context, the Bali Mūla Society as a sub-group of Austronesian peoples in Indonesia, the orientation of the binary opposition (cosmic direction), namely kaje (mountain) - kalod (sea), is very important and influences the structure of space, buildings, and social behavior of people in their daily lives. In general the cosmic direction of kaje is regarded as a more sacred place, because it is viewed as a sanctuary of ancestral spirits and gods or as an axis mundi which connecting human nature / middle nature (bhwarloka) with the realm of gods (upper world/Swarloka), and lowly beings in nature at bottom (bhurloka). This three cosmic realm, in Bali is now commonly known as the Triloka.

Gebog Domas is Bali Mūla (Original Balinese) cosmology which belongs to the Austronesian language family. Literally the word Gebog Domas consists of two words, namely gebog which means an accumulation (segment), and domas which means a number of 800 (eight hundred). Thus the word Gebog Domas literally means an accumulation of eight hundred, which is the name of a traditional institution as a manager (pangempon) of the Pucak Panulisan Temple which located in Sukawana Village, Kintamani District, Bangli Regency. Initially there were about 33 traditional villages that were incorporated in the banua Gebog Domas as the manager of the Pucak Panulisan Temple, but later, for some reason, several traditional villages withdrew and did not participate in the partnership again.

The results of surveys and interviews in the field (May-June 2019), namely in traditional villages which classified as Bali Müla (Bali Aga), show that the organizational structure patterns of traditional villages are relatively similar, which is bound in the unity of the UluApad (upstream-downstream) structure led by a figure, namely Kubayan / Kabayan. The cooperative relationship in the inter-village communion which is spiritual in nature in the management of holy places related to the origin of the same ancestor is also called mabanua. Thus it is known that there are banua Gebog Domas, Banua Gebog Satak, or banua between two neighboring villages, such as Banwa Awan Village and its neighboring village, Serai Village. Based on the inscription data, banua terminology for the first time in Bali has been mentioned in the ancient Balinese inscription, namely the inscription of Bebetin AI (Çaka 818 $=896$ AD).In this inscription was mentioned banwa bharu. Then the inscription Trunyan AI

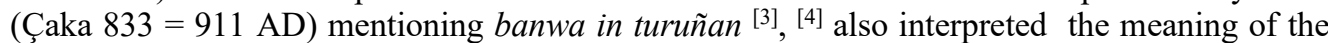
word banua as a network of relationships or social alliance and ritual. Related to the Gebog Domas organization as the manager (pengempon) of Pucak Panulisan Temple, its existence is 
divided into 4 (four) Gebog Satak (cumulative two hundred) which are adjusted to the four main compass directions, namely: (1) Sukawana Traditional Village with its subordinate traditional villages representing the cosmic direction of east (kangin), (2) Kintamani Traditional Village with other traditional villages domiciled as cosmic representations of south (kalod), (3) Selulung Traditional Village with other traditional villages occupying the cosmic position in the west (kauh), and (4) Bantang Traditional Village with other traditional sub-villages as cosmic representations to the north. Based on the results of surveys and interviews in the field, all the traditional villages that are incorporated in the Banua Gebog Domas alliance are oriented towards the Pucak Panulisan Temple of Sukawana Village as a temple on the highest hilltop (1786 m asl) and considered as the most sacred temple and hill. Banua Gebog Domas, which is structured into four Gebog Satak, can be interpreted as a representation of a magical cosmic of mandala, which is a symbol of the universe (macrocosm / bhuwana agung). The four Gebog Satak consist of the cosmic realm of east, south nature, west nature, north cosmic nature, and Pucak Panulisan Temple (Tegeh Koripan Temple) located in the middle on the hilltop, as the center of magical cosmic nature (axis mundi).

The symptom of the mandala concept in the catur bhuwana seems to have been commonly practiced in the mention of 4 village boundaries (çimayangña) in the Ancient Bali Period, which started with mentioning the village boundaries on the kangin side (east), kalod (south), karuh (west), and kadya/kaja (north) as mentioned in the inscription of Bebetin AI (Çaka $818=$ 896 AD), and other inscriptions. The division of the four sacred cosmic (catur bhuwana) with one at the center (middle) is thought to be the original concept of Bali Müla (Austronesian subculture) which then blended with the concept of Hindu cosmology, namely the concept of

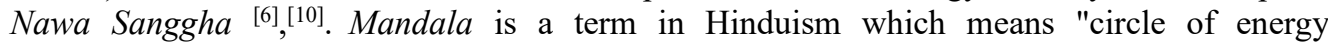
concentration". Mandala is related to the spiral motion of consciousness, sacred geometric, psychology and healing processes. Mandala in Hinduism or Buddhism is something that is spiritual and ritual symbols as a representation of the universe or the macrocosm /bhuwana agung (Universe). The basic form of the mandala is mostly in the form of a rectangle with four gates containing a circle with a concentration point (center) in the middle. In Hindu cosmology, the surface of the bhumi (earth) is represented in a rectangular form which is a very fundamental form in the concept of Hinduism. The earth is represented as a four cornered space associated with the horizon of the sunrise -sunset, the direction of the kaje (mount) - kalod (ocean). Bhumi is thus referred to as "caturbhrsti" (four cornered) and is represented in the symbolic form of Prithhivi Mandala. Circles (rectangles) are representations of protection, good lucks or completion (Source: http://www.crystalinks.com/mandala.html; downloaded March 17, 2017). ${ }^{[11]} A$ mandala in the form of a rectangle that is in a circle that continues to rotate (Prthivi-Mandala or Rectangular Mandala or Chakra-Mandala), is a symbol of the meeting (marriage) between earth (bhumi) with heaven, and symbols of life.

\subsection{The Meaning of Socio-Cultural and Environmental Wisdoms of The Gebog Domas Cosmology}

In the concept of mandala deals with the Gebog Domas cosmology, the Pucak Panulisan Temple site with all of its tangible cultures (artifacts, ecofacts, monuments, sites) and its intangible cultures (myths, rituals, traditional social institutions), contains a variety of sociocultural and environmental wisdoms. In general, in the cosmology of Gebog Domas implicitly contains a strong desire from the people of Ancient Bali (Bali Müla / Bali Aga) to maintain the balance and harmony of life between Bhuwana Alit (Microcosm) and Bhuwana Agung (Macrocosm). In addition, it also contains the values of social integrity, order and peace of life, togetherness (mutual cooperation), and environmental ethics. In the practice of life, cosmology 
of Gebog Domas can be interpreted in the context of the balance and harmony of life in the form of human interaction with others, balance and harmony in human interactions with their natural environment, and humans with the cosmic nature (God) with all of their representations. This interdependent triangle relationship (Human-Nature-God), now in Bali is commonly known as Tri Hita Karana. In a more pragmatic life, worshipping of ancestral spirits and mountain gods, and other supernatural forces (Animism) in the cosmology of Gebog Domas Pucak Panulisan, in general is also associated with water conservation. The main objectives, namely achievement of rahayu (safety and health), fertility and prosperity in agricultural activities, plantations, animal husbandry, and certain other activities. All activities are expected to lead to the highest goal of life, namely sustainable living in welfare atmosphere (jagadhita). But contemporaryly in the Postmodern era, the cultural or environmental wisdoms embodied in the Gebog Domas cosmology is a challenge for local community (Bali-Indonesia) to preserve and implement in real life.

\section{Conclusion}

Based on the analysis and discussion above, the results of the study can be concluded as follows. Cosmology of Gebog Domas of the Pucak Panulisan Temple at Sukawana Village is a worldview of the Bali Mūla (indigenous Balinese) community in Kintamani District. This cosmological system (Gebog Domas) which is devided into four gebog satak (catur bhuwana) is a representation of mandala. The cosmological system of Gebog Domas Pucak Panulisan Temple is interpreted deriving from Pre-Hindu period, especially from megalithic traditions. The cosmology of Gebog Domas of the Pura Pucak Panulisan contains a rich of socio-cultural and environmental wisdoms.

\section{References}

[1] W. . Stutterheim, Oudheiden van Bali (translated by I Gst Ngurah Gede Catra). Denpasar, 1927.

[2] R. Goris, Bali Atlas Kebudayaan (Cults and Customs). Pemerintah Republik Indonesia: Departemen Pendidikan, Pengajaran dan Kebudayaan.

[3] R. Goris, Prasasti Bali I. N.V. Masa Baru, Bandung: Lembaga Bahasa dan Budaya Universitas Indonesia, 1954.

[4] T. A. Reuter, Custodians of The Sacred Mountains: Budaya dan Masyarakat di Pegunungan Bali. Jakarta: Yayasan Obor Indonesia, 2005.

[5] A. M. A. Reader, Myths, Rites, Symbols. London, 1976.

[6] I. N. Wardi, "Marjinalisasi Kearifan Lingkungan Kosmologis Warisan Budaya Pura BatukaruPakendungan di Kabupaten Tabanan Bali," Universitas Udayana. Denpasar, 2018.

[7] David, Nicholas, and C. Carol, Ethnoarchaeology in Action. Cambrigde University Press, 2001.

[8] B. H. Hoed, "Semiotik dan Dinamika Sosial Budaya," Universitas Indonesia, 2008.

[9] I. N. Wardi, I. G. M. Suarbhawa, I. W. Redig, I. W. Suantika, I. P. Y. Haribuana, and R. Suyarto, "Bentang Budaya Kosmologis Kerajaan Bali Kuno: Kajian Kearifan Lingkungan Dalam Upaya Mendukung Pembangunan Berkelanjutan (Zona Hulu: Banua Gebog Domas Pura Pucak Penulisan Kecamatan Kintamani Kabupaten Bangli)," Universitas Udayana, Denpasar, 2019.

[10] J. . Swellengrebel, Patterns of The Cosmic Order" dalam Bali Studies in Life, Thoughts, and Ritual. The Hague and Bandung: The Royal Tropical Institute-Amsterdam.W.van Hoeve Ltd, 1960.

[11] S. Kramrisch, The Hindu Temple. University of Calcutta, 1946. 